\title{
Annex I
}

\begin{tabular}{|c|c|c|}
\hline \multicolumn{3}{|c|}{ International organizations` attendance to the G20 summits } \\
\hline Date & Venue & IOs \\
\hline $\begin{array}{l}\text { November } 14-15 \text {, } \\
2008\end{array}$ & $\begin{array}{l}\text { Washington, the } \\
\text { US }^{1}\end{array}$ & $\begin{array}{l}\text { 1. Financial Stability Forum }(\mathrm{FSF})^{2} \\
\text { 2. International Monetary Fund (IMF) } \\
\text { 3. United Nations (UN) } \\
\text { 4. World Bank }\end{array}$ \\
\hline April 1-2, 2009 & London, the $\mathrm{UK}^{3}$ & $\begin{array}{l}\text { 1. Financial Stability Forum (FSF) } \\
\text { 2. International Monetary Fund (IMF) } \\
\text { 3. United Nations (UN) } \\
\text { 4. World Bank Group } \\
\text { 5. World Trade Organization (WTO) } \\
\text { 6. African Union (AU) } \\
\text { 7. Association of Southeast Asian Nations (ASEAN) } \\
\text { 8. New Partnership for Africa's Development (NEPAD) }\end{array}$ \\
\hline $\begin{array}{l}\text { September } 24-25 \text {, } \\
2009\end{array}$ & Pittsburg, the US & $\begin{array}{l}\text { 1. Financial Stability Forum (FSF) } \\
\text { 2. International Monetary Fund (IMF) } \\
\text { 3. Organisation for Economic Co-operation and Development (OECD) } \\
\text { 4. United Nations (UN) } \\
\text { 5. World Bank Group } \\
\text { 6. World Trade Organization (WTO) } \\
\text { 7. Association of Southeast Asian Nations (ASEAN) } \\
\text { 8. New Partnership for Africa's Development (NEPAD) }\end{array}$ \\
\hline June $26-27,2010$ & Toronto, Canada $^{7}$ & $\begin{array}{l}\text { 1. Financial Stability Board (FSB) } \\
\text { 2. International Labour Organization (ILO) } \\
\text { 3. International Monetary Fund (IMF) } \\
\text { 4. Organisation for Economic Co-operation and Development (OECD) } \\
\text { 5. United Nations (UN) } \\
\text { 6. World Bank Group } \\
\text { 7. World Trade Organization (WTO) } \\
\text { 8. African Union (AU) } \\
\text { 9. Association of Southeast Asian Nations (ASEAN) } \\
\text { 10. New Partnership for Africa's Development (NEPAD) }\end{array}$ \\
\hline $\begin{array}{l}\text { November 11-12, } \\
2010\end{array}$ & $\begin{array}{l}\text { Seoul, the Republic } \\
\text { of Korea }\end{array}$ & $\begin{array}{l}\text { 1. Financial Stability Forum (FSF) } \\
\text { 2. International Labour Organization (ILO) } \\
\text { 3. International Monetary Fund (IMF) } \\
\text { 4. Organisation for Economic Co-operation and Development (OECD) } \\
\text { 5. United Nations (UN) } \\
\text { 6. World Bank Group } \\
\text { 7. World Trade Organization (WTO) } \\
\text { 8. African Union (AU) } \\
\text { 9. Association of Southeast Asian Nations (ASEAN) } \\
\text { 10. Global Governance Group (3G) (Singapore as a chair) } \\
\text { 11. New Partnership for Africa's Development (NEPAD) }\end{array}$ \\
\hline $\begin{array}{l}\text { November 3-4, } \\
2011\end{array}$ & Cannes, France ${ }^{10}$ & $\begin{array}{l}\text { 1. Financial Stability Board (FSB) } \\
\text { 2. International Labour Organization (ILO) } \\
\text { 3. International Monetary Fund (IMF) } \\
\text { 4. Organisation for Economic Co-operation and Development (OECD) } \\
\text { 5. United Nations (UN) } \\
\text { 6. World Bank Group } \\
\text { 7. World Trade Organization (WTO) } \\
\text { 8. African Union (AU) (Equatorial Guinea as a chair) } \\
\text { 9. Association of South East Asian Nations (ASEAN) } \\
\text { 10. Basel Committee on Banking Supervision } \\
\text { 11. Cooperation Council for the Arab States of the Gulf (CCASG) } \\
\text { 12. European Central Bank } \\
\text { 1. Global Governance Group (3G) (Singapore as a chair) } \\
\text { 13. New Partnership for Africa's Development (NEPAD) (Ethiopia as a chair) }\end{array}$ \\
\hline
\end{tabular}




\begin{tabular}{|c|c|c|}
\hline July $18-19,2012$ & Los Cabos, Mexico & $\begin{array}{l}\text { 1. Financial Stability Board (FSB) } \\
\text { 2. International Labour Organization (ILO) } \\
\text { 3. International Monetary Fund (IMF) } \\
\text { 4. Organisation for Economic Co-operation and Development (OECD) } \\
\text { 5. United Nations (UN) } \\
\text { 6. World Bank Group } \\
\text { 7. World Trade Organization (WTO) } \\
\text { 8. African Union (AU) (Malawi as a chair) } \\
\text { 9. Association of South East Asian Nations (ASEAN (Vietnam as a chair) } \\
\text { 10. Food and Agriculture Organization (FAO) } \\
\text { 11. New Partnership for Africa's Development (NEPAD) (Ethiopia as a } \\
\text { chair) }\end{array}$ \\
\hline $\begin{array}{l}\text { September 5-6, } \\
2013\end{array}$ & $\begin{array}{l}\text { St. Petersburg, } \\
\text { Russia }^{12}\end{array}$ & $\begin{array}{l}\text { 1. Financial Stability Board (FSB) } \\
\text { 2. International Labour Organization (ILO) } \\
\text { 3. International Monetary Fund (IMF) } \\
\text { 4. Organisation for Economic Co-operation and Development (OECD) } \\
\text { 5. United Nations (UN) } \\
\text { 6. World Bank Group } \\
\text { 7. World Trade Organization (WTO) } \\
\text { 8. Global Governance Group (3G) (Singapore as a chair) } \\
\text { 9. African Union (Ethiopia as a chair) } \\
\text { 10. Association of Southeast Asian Nations (ASEAN) (Brunei Darussalam } \\
\text { as a chair) } \\
\text { 11. Eurasian Economic Community (EurAsEC) (Kazakhstan as a chair) } \\
\text { 12. New Partnership for Africa's Development (NEPAD) (Senegal as a } \\
\text { chair) }\end{array}$ \\
\hline $\begin{array}{l}\text { November 15-16, } \\
2014\end{array}$ & Brisbane, Australia $^{13}$ & $\begin{array}{l}\text { 1. Financial Stability Board (FSB) } \\
\text { 2. International Labour Organization (ILO) } \\
\text { 3. International Monetary Fund (IMF) } \\
\text { 4. Organisation for Economic Co-operation and Development (OECD) } \\
\text { 5. United Nations (UN) } \\
\text { 6. World Bank (WB) } \\
\text { 7. World Trade Organization (WTO) } \\
\text { 8. African Union (AU) (Mauritania as a chair) } \\
\text { 9. Association of Southeast Asian Nations (ASEAN) (Myanmar as a chair) } \\
\text { 10. New Partnership for Africa's Development (NEPAD) (Senegal as } \\
\text { Steering Committee Chair) }\end{array}$ \\
\hline $\begin{array}{l}\text { November } 15-16 \text {, } \\
2015\end{array}$ & Antalya, Turkey ${ }^{14}$ & $\begin{array}{l}\text { 1. Financial Stability Board (FSB) } \\
\text { 2. International Labour Organization (ILO) } \\
\text { 3. International Monetary Fund (IMF) } \\
\text { 4. Organisation for Economic Co-operation and Development (OECD) } \\
\text { 5. United Nations (UN) } \\
\text { 6. World Bank } \\
\text { 7. World Trade Organization (WTO) } \\
\text { 8. African Union (AU) (Zimbabwe as a chair) } \\
\text { 9. Association of Southeast Asian Nations (ASEAN) (Malaysia as a chair) } \\
\text { 10. New Partnership for Africa's Development (NEPAD) (Senegal as } \\
\text { Steering Committee chair) }\end{array}$ \\
\hline $\begin{array}{l}\text { September 4-5, } \\
2016\end{array}$ & Hangzhou, China & $\begin{array}{l}\text { 1. Financial Stability Board (FSB) } \\
\text { 2. International Labour Organization (ILO) } \\
\text { 3. International Monetary Fund (IMF) } \\
\text { 4. Organisation for Economic Co-operation and Development (OECD) } \\
\text { 5. United Nations (UN) } \\
\text { 6. World Bank } \\
\text { 7. World Trade Organization (WTO) } \\
\text { 8. African Union (AU) (Chad as a chair) } \\
\text { 9. Association of Southeast Asian Nations (ASEAN) (Laos as a chair) }{ }^{15} \\
\text { 10. New Partnership for Africa's Development (NEPAD) (Senegal as a } \\
\text { chair) }\end{array}$ \\
\hline
\end{tabular}


${ }^{1}$ Chapter 3. Plans for the First G20 Leaders Meeting. Available at: http://www.g20.utoronto.ca/g20leadersbook/guebert.html (accessed: 29 August 2016).

${ }^{2}$ The IOs permanently invited to the G20 summits are marked in bold.

${ }^{3}$ Plans for the London G20 Summit 2009. Available at: https://www.google.ru/url?sa=t\&rct=j\&q=\&esr $\mathrm{c}=\mathrm{s} \&$ source $=$ web\&cd=6\&ved $=0$ ahUKEwiyxInB0arOAhXldpoKHSZ6BV0QFghDMAU\&url $=\mathrm{http} \% 3 \mathrm{~A} \% 2 \mathrm{~F}$ \%2Fwww.g8.utoronto.ca\%2Fg20\%2Fg20plans\%2Fg20leaders090309.pdf\&usg=AFQjCNGWU2YRfB0fv73Y NcD7pqExOoKVrw (accessed: 29 August 2016).

${ }^{4}$ Press Release. Secretary-General of ASEAN to attend G20 Summit in London. Available at: http:// www.asean.org/uploads/archive/PR-ASEAN-at-G20.pdf (accessed: 29 August 2016).

${ }^{5}$ OECD's participation in the G20 became more formal as President Obama invited the OECD Secretary-General to the Pittsburgh Summit and to designate a G20 Sherpa to represent the Organisation in the preparatory work. Pittsburgh, United States 2009. Available at: https://www.oecd.org/g20/summits/pittsburgh/ (accessed: 29 August 2016).

${ }^{6}$ We appreciated the invitation to the ASEAN Chair to the G20 Summits in London and Pittsburgh. Chairman's Statement of the 4th East Asia Summit Cha-am Hua Hin, Thailand, 25 October 2009. Available at: http://asean.org/?static post=chairman-s-statement-of-the-4th-east-asia-summit-cha-am-hua-hin-thailand-25-october-2009-2 (accessed: 29 August 2016).

${ }^{7}$ G20 Toronto Summit Participants. Available at: http://www.g20.utoronto.ca/2010/to-participants. html (accessed: 29 August 2016).

${ }^{8}$ ASEAN to attend G20 Summit in Toronto. Available at: http://en.people. cn/90001/90777/90856/7035665.html (accessed: 29 August 2016).

${ }^{9}$ G20. Singapore MFA. Available at: https://www.mfa.gov.sg/content/mfa/international_organisation_ initiatives/g20.html (accessed: 29 August 2016).

${ }^{10}$ Invitation to non-members of the G20 to the G20 Summit of Cannes. Available at: http://www.ambafrance-ca.org/Invitation-to-non-members-of-the (accessed: 29 August 2016).

${ }^{11}$ Chair of ASEAN, President SBY of Indonesia Invites Members of G20 to Join ASEAN in Search of Lasting Solutions to Global Challenges. Available at: http://asean.org/chair-of-asean-president-sby-of-indonesia-invites-members-of-g20-to-join-asean-in-search-of-lasting-solutions-to-global-challenges/ (accessed: 29 August 2016).

12 Official photo of the G20 summit. Available at: http://ru.g20russia.ru/photo/20130906/782752767. html (accessed: 29 August 2016).

${ }^{13}$ G20 Brisbane Summit (Summary). Available at: http://www.mofa.go.jp/ecm/ec/page22e_000624. html (accessed: 29 August 2016).

${ }_{14}$ International Organisations. Available at: http://g20.org.tr/about-g20/g20-members/internationalorganisations/; G20 Leaders' Summit was held in Antalya. Available at: http://www.mfa.gov.tr/g20-leaders_summit-was-held-in-antalya.en.mfa (accessed: 29 August 2016).

15 Wang Yi: Hangzhou Summit - the G20 Summit Participated by the Most Developing Countries. Available at: http://www.fmprc.gov.cn/mfa_eng/zxxx_662805/t1387145.shtml (accessed: 29 August 2016). 


\section{Annex II}

\begin{tabular}{|c|c|c|}
\hline Summit & $\begin{array}{l}\text { Organization and number of } \\
\text { reports submitted }\end{array}$ & Reports \\
\hline $\begin{array}{l}2008 \\
\text { Washington, } \\
\text { the US }\end{array}$ & No & No \\
\hline \multirow[t]{7}{*}{$\begin{array}{l}2009 \\
\text { London, the } \\
\text { UK }\end{array}$} & $\begin{array}{l}\text { International Monetary Fund } \\
(\mathrm{IMF})^{16}-2\end{array}$ & $\begin{array}{l}\text { 1. IMF Staff Note to G-20 } \\
\text { 2. IMF Staff Note Stocktaking of the G-20 Responses to the Global } \\
\text { Banking Crisis }\end{array}$ \\
\hline & Financial Stability Board ${ }^{17}-0$ & No \\
\hline & World Bank -0 & No \\
\hline & $\begin{array}{l}\text { Organization for Economic } \\
\text { Cooperation and Development } \\
(\text { OECD })-0\end{array}$ & No \\
\hline & $\begin{array}{l}\text { International Labour } \\
\text { Organization (ILO) }{ }^{18}-1\end{array}$ & 1. The Financial and Economic Crisis: A Decent Work Response \\
\hline & $\begin{array}{l}\text { World Trade Organization } \\
\text { (WTO) }-0\end{array}$ & No \\
\hline & In total: 3 & \\
\hline \multirow[t]{7}{*}{$\begin{array}{l}2009 \\
\text { Pittsburg, } \\
\text { the US }\end{array}$} & $\begin{array}{l}\text { International Monetary Fund } \\
\text { (IMF) }-2\end{array}$ & $\begin{array}{l}\text { 1. IMF Staff Note to G-20 } \\
\text { 2. The Financial Crisis and Information Gaps (Joint IMF \& FSB Report } \\
\text { to G-20) }\end{array}$ \\
\hline & Financial Stability Board - 2 & $\begin{array}{l}\text { 1. Overview of Progress in the Implementing the London Summit } \\
\text { Recommendations of for Strengthening Financial Stability } \\
\text { 2. Improving financial regulation - Report of the Financial Stability } \\
\text { Board to G20 Leaders }\end{array}$ \\
\hline & World Bank -0 & No \\
\hline & $\begin{array}{l}\text { Organization for Economic } \\
\text { Cooperation and Development } \\
(\text { OECD })^{19}-1\end{array}$ & 1. OECD Note on Growth and Structural Reforms \\
\hline & $\begin{array}{l}\text { International Labour } \\
\text { Organization (ILO) }-2\end{array}$ & $\begin{array}{l}\text { 1. ILO report to the G20: A survey of country employment and social } \\
\text { protection policy responses to the global economic crisis } \\
\text { 2. ILO communication to the G20: Protecting people, promoting jobs: } \\
\text { from crisis response to recovery and sustainable growth }\end{array}$ \\
\hline & $\begin{array}{l}\text { World Trade Organization } \\
\text { (WTO) }-1\end{array}$ & $\begin{array}{l}\text { 1. Report on G20 Trade and Investment Measures (WTO, OECD, } \\
\text { UNCTAD) }\end{array}$ \\
\hline & In total: 8 & \\
\hline \multirow[t]{3}{*}{$\begin{array}{l}2010 \\
\text { Toronto, } \\
\text { Canada }\end{array}$} & $\begin{array}{l}\text { International Monetary Fund } \\
\text { (IMF) }-4\end{array}$ & $\begin{array}{l}\text { 1. IMF Staff Note to G-20 } \\
\text { 2. The Financial Crisis and Information Gaps: Progress Report, Action } \\
\text { Plans, and Timetables } \\
\text { 3. G-20 Mutual Assessment Process-Alternative Policy Scenarios } \\
\text { 4. Principles for Innovative Financial Inclusion - Financial Sector } \\
\text { Taxation - The IMF's Report to the G-20 and Background Material }\end{array}$ \\
\hline & Financial Stability Board -3 & $\begin{array}{l}\text { 1. Progress since the Pittsburgh Summit in Implementing the G20 } \\
\text { Recommendations for Strengthening Financial Stability } \\
\text { 2. Exit from extraordinary financial sector support measures } \\
\text { 3. Guidance to Assess the Systemic Importance of Financial Institutions }\end{array}$ \\
\hline & World Bank -2 & $\begin{array}{l}\text { 1. G20 AND GLOBAL DEVELOPMENT } \\
\text { 2. The scope of fossil-fuel subsidies in } 2009 \text { and a roadmap for phasing } \\
\text { out fossil fuel subsidies (IEA, OECD, World Bank) }\end{array}$ \\
\hline
\end{tabular}




\begin{tabular}{|c|c|c|}
\hline \multirow[t]{5}{*}{ Summit } & $\begin{array}{l}\text { Organization and number of } \\
\text { reports submitted }\end{array}$ & Reports \\
\hline & $\begin{array}{l}\text { International Labour } \\
\text { Organization (ILO) }-3\end{array}$ & $\begin{array}{l}\text { 1. Employment and social protection policies from crisis to recovery and } \\
\text { beyond: A review of experience An ILO report to the G20 Labour and } \\
\text { Employment Ministers Meeting } \\
\text { 2. Accelerating a job-rich recovery in G20 countries: Building on } \\
\text { experience } \\
\text { 3. Employment and labour market adjustments in G20 Countries during } \\
\text { 2007-09 and outlook for 2010: A statistical overview }\end{array}$ \\
\hline & $\begin{array}{l}\text { World Trade Organization } \\
\text { (WTO) }-1\end{array}$ & $\begin{array}{l}\text { 1. Report on G20 trade and investment measures (November } 2009 \text { to mid- } \\
\text { May 2010) }\end{array}$ \\
\hline & $\begin{array}{l}\text { United Nations Conference } \\
\text { on Trade and Development } \\
\text { (UNCTAD) }-1\end{array}$ & 1. Third report on G20 investment measures (OECD, UNCTAD) \\
\hline & In total: 14 & \\
\hline \multirow{9}{*}{$\begin{array}{l}2010 \text { Seoul, } \\
\text { the Republic } \\
\text { of Korea }\end{array}$} & $\begin{array}{l}\text { International Monetary Fund } \\
\text { (IMF) }-1\end{array}$ & 1. IMF Report on G-20 Mutual Assessment Process (MAP) \\
\hline & Financial Stability Board -3 & $\begin{array}{l}\text { 1. Progress since the Washington Summit in the Implementation of the G20 } \\
\text { Recommendations for Strengthening Financial Stability } \\
\text { 2. The Financial Crisis and Information Gaps - Action Plans and } \\
\text { Timetables } \\
\text { 3. Reducing the Moral Hazard Posed by Systemically Important } \\
\text { Financial Institutions }\end{array}$ \\
\hline & World Bank -0 & No \\
\hline & $\begin{array}{l}\text { Organization for Economic } \\
\text { Cooperation and Development } \\
(\text { OECD })^{20}-3\end{array}$ & $\begin{array}{l}\text { 1. Pursuing Strong, Sustainable and Balanced Growth: the Role of } \\
\text { Structural Reform } \\
\text { 2. Progress Report on the Jurisdictions Surveyed by the OECD Global } \\
\text { Forum in Implementing the Internationally Agreed Tax Standard } \\
\text { 3. Seizing the Benefits of Trade for Employment and Growth (OECD, } \\
\text { ILO, World Bank, WTO) }\end{array}$ \\
\hline & $\begin{array}{l}\text { International Labour } \\
\text { Organization (ILO) }-0\end{array}$ & No \\
\hline & $\begin{array}{l}\text { World Trade Organization } \\
\text { (WTO) }-0\end{array}$ & No \\
\hline & $\begin{array}{l}\text { United Nations Conference } \\
\text { on Trade and Development } \\
\text { (UNCTAD) }-0\end{array}$ & No \\
\hline & $\begin{array}{l}\text { International Energy Agency } \\
\text { (IEA) }-1\end{array}$ & $\begin{array}{l}\text { 1. The Scope of Fossil-Fuel Subsidies in } 2009 \text { and a Roadmap for Phasing } \\
\text { out Fossil-Fuel Subsidies (IEA, OECD, World Bank) }\end{array}$ \\
\hline & In total: 8 & \\
\hline \multirow[t]{3}{*}{$\begin{array}{l}2011 \\
\text { Cannes, } \\
\text { France }\end{array}$} & $\begin{array}{l}\text { International Monetary Fund } \\
\text { (IMF) }-4\end{array}$ & $\begin{array}{l}\text { 1. IMF Staff Note to G-20 } \\
\text { 2. IMF Staff Reports for the G-20 Mutual Assessment Process } \\
\text { 3. The Financial Crisis and Information Gaps (Joint IMF \& FSB Report } \\
\text { to G-20) } \\
\text { 4. Supporting the Development of More Effective Tax Systems - A } \\
\text { Report to the G20 Development Working Group by the IMF, OECD, } \\
\text { UN and World Bank }\end{array}$ \\
\hline & Financial Stability Board -2 & $\begin{array}{l}\text { 1. Overview of Progress in the Implementation of the G20 } \\
\text { Recommendations for Strengthening Financial Stability } \\
\text { 2. Financial Stability Issues in Emerging Market and Developing } \\
\text { Economies - Report to the G-20 Finance Ministers and Central Bank } \\
\text { Governors by A Task Force of the FSB and Staff of the IMF and the } \\
\text { World Bank }\end{array}$ \\
\hline & World Bank - 1 & $\begin{array}{l}\text { 1. Mobilizing Climate Finance - A Paper prepared at the request of G20 } \\
\text { Finance Ministers }\end{array}$ \\
\hline
\end{tabular}




\begin{tabular}{|c|c|c|}
\hline Summit & $\begin{array}{l}\text { Organization and number of } \\
\text { reports submitted }\end{array}$ & Reports \\
\hline & $\begin{array}{l}\text { Organization for Economic } \\
\text { Cooperation and Development } \\
(\mathrm{OECD})^{21}-3\end{array}$ & $\begin{array}{l}\text { 1. Global Forum on Transparency and Exchange of Information for Tax } \\
\text { Purposes. Tax Transparency 2011: Report on Progress } \\
\text { 2. G20: Pursuing Strong, Sustainable and Balanced Growth: Taking stock } \\
\text { of structural reform commitments } \\
\text { 3. G20 High-Level Principles on Financial Consumer Protection }\end{array}$ \\
\hline & $\begin{array}{l}\text { World Trade Organization } \\
\text { (WTO) }-1\end{array}$ & 1. Report on G20 Trade Measures \\
\hline & $\begin{array}{l}\text { United Nations Conference } \\
\text { on Trade and Development } \\
\text { (UNCTAD) }-3\end{array}$ & $\begin{array}{l}\text { 1. Promoting standards for responsible investment in value chains. Report } \\
\text { to the High-Level Development Working Group (UNCTAD, OECD, } \\
\text { UN, ILO, WB) } \\
\text { 2. Indicators for measuring and maximizing economic value added and } \\
\text { job creation arising from private sector investment in value chains. Report } \\
\text { to the High-Level Development Working Group (UNCTAD, OECD, } \\
\text { UN, ILO, WB) } \\
\text { 3. OECD/UNCTAD report on G20 investment measures }\end{array}$ \\
\hline & $\begin{array}{l}\text { Bank for International } \\
\text { Settlements (BIS) }-2\end{array}$ & $\begin{array}{l}\text { 1. Global systemically important banks: Assessment methodology and } \\
\text { the additional loss absorbency requirement } \\
\text { 2. Macroprudential policy tools and frameworks. Update to G20 Finance } \\
\text { Ministers and Central Bank Governors (FSB, IMF, BIS) }\end{array}$ \\
\hline & $\begin{array}{l}\text { International Organization } \\
\text { of Securities Commissions } \\
(\text { IOSCO })-2\end{array}$ & $\begin{array}{l}\text { 1. Task Force on Commodity Futures Markets. Report to the Financial } \\
\text { Stability Board } \\
\text { 2. Principles for the Regulation and Supervision of Commodity } \\
\text { Derivatives Markets }\end{array}$ \\
\hline & $\begin{array}{l}\text { Global Partnership for } \\
\text { Financial Inclusion (GPFI) } \\
-1\end{array}$ & 1. Global Partnership for Financial Inclusion report to Leaders \\
\hline & $\begin{array}{l}\text { Food and Agriculture } \\
\text { Organization of the United } \\
\text { Nations }(\text { FAO })-1\end{array}$ & $\begin{array}{l}\text { 1. Price Volatility in Food and Agricultural Markets: Policy Responses } \\
\text { (FAO, IFAD, IMF, OECD, UNCTAD, WFP, World Bank, WTO, IFPRI, } \\
\text { UN HLTF) }\end{array}$ \\
\hline & $\begin{array}{l}\text { International Energy Agency } \\
\text { (IEA) }-2\end{array}$ & $\begin{array}{l}\text { 1. Joint report by IEA, OPEC, OECD and World Bank on fossil-fuel } \\
\text { and other energy subsidies: An update of the G20 Pittsburgh and Toronto } \\
\text { Commitments } \\
\text { 2. Extending the G20 Work on Oil price Volatility to Coal and Gas (IEA, } \\
\text { IEF, IMF, OPEC) }\end{array}$ \\
\hline & In total: 22 & \\
\hline $\begin{array}{l}2012 \text { Los } \\
\text { Cabos, } \\
\text { Mexico }\end{array}$ & $\begin{array}{l}\text { International Monetary Fund } \\
\text { (IMF) }-5\end{array}$ & $\begin{array}{l}\text { 1. IMF Staff Note to G-20 } \\
\text { 2. IMF Staff Reports for the G-20 Mutual Assessment Process } \\
\text { 3. The Financial Crisis and Information Gaps - Progress Report on the } \\
\text { G-20 Data Gaps Initiative: Status, Action Plans, and Timetables } \\
\text { 4. Recent Developments in Fuel Pricing and Fiscal Implications } \\
\text { 5. Macroeconomic Policy Challenges from Commodity Price Volatility }\end{array}$ \\
\hline & Financial Stability Board -8 & $\begin{array}{l}\text { 1. Overview of Progress in the Implementation of the G20 } \\
\text { Recommendations for Strengthening Financial Stability } \\
\text { 2. Strengthening the Oversight and Regulation of Shadow Banking. } \\
\text { Progress Report to G20 Ministers and Governors } \\
\text { 3. Extending the G-SIFI Framework to Domestic Systemically } \\
\text { Important Banks } \\
\text { 4. Identifying the Effects of Regulatory Reforms on Emerging Market } \\
\text { and Developing Economies: A Review of Potential Unintended } \\
\text { Consequences } \\
\text { 5. Report to the G20 Los Cabos Summit on Strengthening FSB } \\
\text { Capacity, Resources and Governance } \\
\text { 6. Progress Report on Increasing the Intensity and Effectiveness of SIFI } \\
\text { Supervision } \\
\text { 7. Implementing the Global Legal Entity Identifier (LEI) System - A } \\
\text { Charter for the Regulatory Oversight Committee and Report on Progress } \\
\text { 8. Roadmap for Reducing Reliance on CRA Ratings }\end{array}$ \\
\hline
\end{tabular}




\begin{tabular}{|c|c|c|}
\hline Summit & $\begin{array}{l}\text { Organization and number of } \\
\text { reports submitted }\end{array}$ & Reports \\
\hline & World Bank -8 & $\begin{array}{l}\text { 1. Financial Inclusion Strategies Reference Framework } \\
\text { 2. Restoring and Sustaining Growth } \\
\text { 3. Market-Based Approaches to Managing Commodity Price Risk } \\
\text { 4. Reducing Distortions in International Commodity Markets: An } \\
\text { Agenda for Multilateral Cooperation } \\
\text { 5. The Role of Emerging-Market Economy Demand during the Post- } \\
\text { 2005 Boom } \\
\text { 6. Facilitating Short and Longer-term Supply Response to Higher and } \\
\text { More Volatile Food Prices } \\
\text { 7. Transmission of Global Food Prices to Domestic Prices in Developing } \\
\text { Countries: Why It Matters, How It Works, and Why It Should Be } \\
\text { Enhanced22 } \\
\text { 8. Supporting the Development of Local Currency Bond Markets (World } \\
\text { Bank, Regional Development Banks, IMF, OECD and the Bank of } \\
\text { International Settlements (BIS)) }\end{array}$ \\
\hline & $\begin{array}{l}\text { Organization for Economic } \\
\text { Cooperation and Development } \\
(\text { OECD })^{23}-8\end{array}$ & $\begin{array}{l}\text { 1. Economic Policy Reforms: Going for Growth } 2012 \\
\text { 2. Global Forum on Transparency and Exchange the Information for Law } \\
\text { Purposes. Progress Report to the G20 } \\
\text { 3. Tackling Offhore Tax Evasion the G20/OECD Continues to Make } \\
\text { Progress. THE G20/OECD CONTINUES TO MAKE PROGRESS JUNE } \\
\text { 2012 (REPORT BY SECRETARY-GENERAL GURRÍA OF THE OECD) } \\
\text { 4. Pursuing Strong, Sustainable and Balanced Growth: a Note on } \\
\text { Implementation of G20 Structural Reform Commitments } \\
\text { 5. Effective Approaches to Support the Implementation of the G20 High- } \\
\text { Level Principles on Financial Consumer Protection (Draft Action Plan of } \\
\text { the G20/OECD Task Force on Financial Consumer Protection) } \\
\text { 6. The challenge of promoting youth employment in the G20 countries } \\
\text { 7. Policy Note on Pension Fund Financing for Green Infrastructure and } \\
\text { Initiatives (OECD, G20) } \\
\text { 8. Incorporating green growth and sustainable development policies into } \\
\text { structural reform agendas (OECD, UN, World Bank) }\end{array}$ \\
\hline & $\begin{array}{l}\text { International Labour } \\
\text { Organization (ILO) }-5\end{array}$ & $\begin{array}{l}\text { 1. ILO Note on Youth employment in G20 countries } \\
\text { 2. Boosting jobs and living standards in G20 countries (ILO, OECD, } \\
\text { IMF, World Bank) } \\
\text { 3. Progress report on the Human Resource Development Pillar (ILO, } \\
\text { OECD, UNESCO, the World Bank) } \\
\text { 4. Sustainable development, green growth and quality employment (ILO, } \\
\text { OECD) } \\
\text { 5. Short-term labour market outlook and key challenges in G20 countries } \\
\text { (ILO, OECD) }\end{array}$ \\
\hline & $\begin{array}{l}\text { World Trade Organization } \\
\text { (WTO) }-1\end{array}$ & 1. WTO Report on G-20 Trade Measures \\
\hline & $\begin{array}{l}\text { United Nations Conference } \\
\text { on Trade and Development } \\
\text { (UNCTAD) }-2\end{array}$ & $\begin{array}{l}\text { 1. Promoting responsible investment for sustainable development and job } \\
\text { creation. Final report to the High-Level Development Working Group on } \\
\text { the work of the Private Investment and Job Creation Pillar (UNCTAD, } \\
\text { ILO, UNDP, WB Group and OECD) } \\
\text { 2. Excessive Commodity Price Volatility: Macroeconomic Effects on } \\
\text { Growth and Policy Options }\end{array}$ \\
\hline & $\begin{array}{l}\text { International Organization } \\
\text { of Securities Commissions } \\
\text { (IOSCO) }-3\end{array}$ & $\begin{array}{l}\text { 1. The Credit Default Swap Market } \\
\text { 2. Update to G20 on IOSCO's Work on Market Integrity and Efficiency } \\
\text { 3. IOSCO's Consultation on the Functioning and Oversight of Oil Price } \\
\text { Reporting Agencies }\end{array}$ \\
\hline & $\begin{array}{l}\text { Global Partnership for } \\
\text { Financial Inclusion (GPFI) }-1\end{array}$ & 1. GPFI Follow Up Report to G20 Leaders \\
\hline & $\begin{array}{l}\text { Financial Action Task Force } \\
\text { (FATF) }-2\end{array}$ & $\begin{array}{l}\text { 1. Report to G20 Leaders by the Financial Action Task Force } \\
\text { 2. The new FATF Standards }\end{array}$ \\
\hline & $\begin{array}{l}\text { Food and Agriculture } \\
\text { Organization of the United } \\
\text { Nations (FAO) }-1\end{array}$ & $\begin{array}{l}\text { 1. Sustainable Agricultural Productivity Growth and Bridging the Gap } \\
\text { for Small Family Farms (Bioversity, CGIAR Consortium, FAO, IFAD, } \\
\text { IFPRI, IICA, OECD, UNCTAD, UN High Level Task Force on the } \\
\text { Food Security Crisis, WFP, World Bank, and WTO) }\end{array}$ \\
\hline & African Development Bank - 1 & $\begin{array}{l}\text { 1. A Toolkit of Policy Options to Support Inclusive Green Growth } \\
\text { (AfDB, OECD, UN World Bank) }\end{array}$ \\
\hline & In total: 45 & \\
\hline
\end{tabular}




\begin{tabular}{|c|c|c|}
\hline Summit & $\begin{array}{l}\text { Organization and number of } \\
\text { reports submitted }\end{array}$ & Reports \\
\hline \multirow[t]{4}{*}{$\begin{array}{l}2013 \text { St. } \\
\text { Petersburg, } \\
\text { Russia }\end{array}$} & $\begin{array}{l}\text { International Monetary Fund } \\
(\mathrm{IMF})-4\end{array}$ & $\begin{array}{l}\text { 1. IMF Staff Note to G-20, and Annex } \\
\text { 2. The Financial Crisis and Information Gaps - Fourth Implementation } \\
\text { Progress Report } \\
\text { 3. 2013 Update of Staff Sustainability Assessments for G-20 Mutual } \\
\text { Assessment Process (MAP) } \\
\text { 4. Local Currency Bond Markets: A Diagnostic Framework (IMF, World } \\
\text { Bank, EBRD, OECD) }\end{array}$ \\
\hline & Financial Stability Board - 10 & $\begin{array}{l}\text { 1. Overview of Progress in the Implementation of the G20 } \\
\text { Recommendations for Strengthening Financial Stability } \\
\text { 2. Financial regulatory factors affecting the availability of long-term } \\
\text { investment finance } \\
\text { 3. Implementing the FSB Key Attributes of Effective Resolution Regimes } \\
\text { - how far have we come? } \\
\text { 4. Global systemically important insurers (G-SIIs) and the policy } \\
\text { measures that will apply to them } \\
\text { 5. An Overview of Policy Recommendations for Shadow Banking } \\
\text { 6. Report to the G20 on Progress Toward Reducing Reliance and } \\
\text { Strengthening Oversight of Credit Rating Agencies } \\
\text { 7. Progress Report on the Oversight and Governance Framework for } \\
\text { Financial Benchmark Reform } \\
\text { 8. FSB Chairman's Report on OTC Derivatives Reforms } \\
\text { 9. Progress and Next Steps Towards Ending «Too-Big-To-Fail» (TBTF) } \\
\text { 10. Narrative progress report on financial reforms }\end{array}$ \\
\hline & World Bank - 6 & $\begin{array}{l}\text { 1. Long-Term Investment Financing for Growth and Development: } \\
\text { Umbrella Paper (February 2013) } \\
\text { 2. Recent Developments in Local Currency Bond Markets (LCBMs). } \\
\text { Note by the World Bank Group in consultation with the IMF, ADB, AfDB, } \\
\text { IADB, EBRD, OECD, and BIS to the G20 Finance Ministers and Central } \\
\text { Bank Governors } \\
\text { 3. Addressing the Jobs Challenge in G20 Countries. An overview of } \\
\text { recent labor market trends and policies } \\
\text { 4. Women and Finance. Progress Report to the G20 (World Bank, } \\
\text { OECD/INFE) } \\
\text { 5. Updating the Guidelines for Public Debt Management. Progress } \\
\text { Report by the IMF and the World Bank Group to the G20 Ministerial } \\
\text { Meeting } \\
\text { 6. Demand for Long Term Financing for Sustainable Development. } \\
\text { Issues Note (No. 7) for Consideration by G20 }\end{array}$ \\
\hline & $\begin{array}{l}\text { Organization for Economic } \\
\text { Cooperation and Development } \\
(\text { OECD })^{24}-21\end{array}$ & $\begin{array}{l}\text { 1. Economic Policy Reforms: Going for Growth } \mathbf{2 0 1 3} \\
\text { 2. OECD Secretary-General Tax Report to G20 } \\
\text { 3. The Role of Banks, Equity Markets and Institutional Investors in } \\
\text { Long-Term Financing for Growth and Development. Report for G20 } \\
\text { Leaders } \\
\text { 4. Declaration on Base Erosion and Profit Shifting } \\
\text { 5. Tools to Promote Financial Education. Progress Report to the G20 } \\
\text { (OECD, World Bank) } \\
\text { 6. Activation Strategies for Stronger and More Inclusive Labour Markets } \\
\text { in G20 Countries: Key Policy Challenges and Good Practices } \\
\text { 7. Evaluating Financial Education Programmes: OECD/INFE Survey, } \\
\text { Framework, Policy Instruments and Guidance } \\
\text { 8. OECD/INFE Analysis on Women and Financial Education: } \\
\text { Evidence, Policy Response and Guidance } \\
\text { 9. OECD/INFE Toolkit to Measure Financial Literacy and Inclusion: } \\
\text { Guidance, Core Questionnaire and Supplementary Questions } \\
\text { 10. OECD/INFE Policy Guidance on Addressing Women's and Girls' } \\
\text { Needs for Financial Awareness and Education } \\
\text { 11. G20/OECD Task Force on Financial Consumer Protection - } \\
\text { Summary Report on Effective Approaches to Support the Implementation } \\
\text { of the G20 High-Level Principles on Financial Consumer Protection } \\
\text { 12. Action Plan on Base Erosion and Profit Shifting }\end{array}$ \\
\hline
\end{tabular}




\begin{tabular}{|c|c|c|}
\hline Summit & $\begin{array}{l}\text { Organization and number of } \\
\text { reports submitted }\end{array}$ & Reports \\
\hline & & $\begin{array}{l}\text { 13. Implications of Global Value Chains for Trade, Investment, } \\
\text { Development and Jobs (OECD, WTO, UNCTAD) } \\
\text { 14. G20-OECD High-Level Principles of Long-Term Investment } \\
\text { Financing by Institutional Investors } \\
\text { 15. Policy Guidance for Investment in Clean Energy Infrastructure: } \\
\text { Expanding Access to Clean Energy for Growth and Development } \\
\text { (OECD, World Bank, UNDP) } \\
\text { 16. "Update Report on the Work to Support the Implementation of the } \\
\text { G20 High-level Principles on Financial Consumer Protection" (G20/ } \\
\text { OECD Task Force on Financial Consumer Protection) } \\
\text { 17. Advancing National Strategies for Financial Education (Russia's G20 } \\
\text { Presidency, OECD) } \\
\text { 18. A Note on G20 Structural Reform Commitments - Pursuing Strong, } \\
\text { Sustainable and Balanced Growth (OECD, World Bank) } \\
\text { 19. Issues Paper on Corruption and Economic Growth } \\
\text { 20. Indicators of skills for employment and productivity: a conceptual } \\
\text { Framework and approach for low-income countries (OECD, World } \\
\text { Bank, ETF, ILO, UNESCO) } \\
\text { 21. Anti-Corruption Ethics and Compliance Handbook for Business } \\
\text { (OECD, UNODC and World Bank) }\end{array}$ \\
\hline & $\begin{array}{l}\text { International Labour } \\
\text { Organization (ILO) }-2\end{array}$ & $\begin{array}{l}\text { 1. Short-term labour market outlook and key challenges in G20 countries } \\
\text { (ILO, OECD) } \\
\text { 2. Addressing employment, labour market and social protection } \\
\text { challenges in G20 countries: Key measures since } 2010 \text { (ILO, OECD) }\end{array}$ \\
\hline & $\begin{array}{l}\text { World Trade Organization } \\
\text { (WTO) }-2\end{array}$ & $\begin{array}{l}\text { 1. Report on G-20 Trade Measures } \\
\text { 2. Aid for Trade at a Glance: Connecting to Value Chains (OECD, } \\
\text { WTO) }\end{array}$ \\
\hline & $\begin{array}{l}\text { United Nations Conference } \\
\text { on Trade and Development } \\
\text { (UNCTAD) }-1\end{array}$ & 1. OECD-UNCTAD Report on G20 Investment Measures \\
\hline & $\begin{array}{l}\text { Bank for International } \\
\text { Settlements (BIS) }-2\end{array}$ & $\begin{array}{l}\text { 1. Global Liquidity: Selected Indicators. Note by the BIS } \\
\text { 2. Report to G20 Finance Ministers and Central Bank Governors on } \\
\text { monitoring implementation of Basel III regulatory reform (Basel Committee } \\
\text { on Banking Supervision, Bank for International Settlements (BIS) }\end{array}$ \\
\hline & $\begin{array}{l}\text { International Organization } \\
\text { of Securities Commissions } \\
\text { (IOSCO) }-1\end{array}$ & $\begin{array}{l}\text { 1. Margin requirements for non-centrally cleared derivatives (Basel } \\
\text { Committee on Banking Supervision, Board of the International } \\
\text { Organization of Securities Commissions) }\end{array}$ \\
\hline & $\begin{array}{l}\text { Basel Committee on Banking } \\
\text { Supervision }-3\end{array}$ & $\begin{array}{l}\text { 1. Report to G20 Finance Ministers and Central Bank Governors } \\
\text { on monitoring implementation of Basel III regulatory reform (Basel } \\
\text { Committee on Banking Supervision, Bank for International Settlements } \\
\text { (BIS) } \\
\text { 2. Basel Committee on Banking Supervision - Report to G20 Leaders on } \\
\text { monitoring implementation of Basel III regulatory reforms } \\
\text { 3. Margin requirements for non-centrally cleared derivatives (Basel } \\
\text { Committee on Banking Supervision, Board of the International } \\
\text { Organization of Securities Commissions) }\end{array}$ \\
\hline & $\begin{array}{l}\text { Global Partnership for } \\
\text { Financial Inclusion (GPFI) }-1\end{array}$ & 1. Global Partnership for Financial Inclusion Report to the Leaders \\
\hline & $\begin{array}{l}\text { African Development } \\
\text { Bank }-1\end{array}$ & $\begin{array}{l}\text { 2. A Toolkit of Policy Options to Support Inclusive Green Growth } \\
\text { (AfDB, OECD, UN World Bank) }\end{array}$ \\
\hline & In total: 55 & \\
\hline $\begin{array}{l}2014 \\
\text { Brisbane, } \\
\text { Australia }\end{array}$ & $\begin{array}{l}\text { International Monetary Fund } \\
\text { (IMF) }-8\end{array}$ & $\begin{array}{l}\text { 1. IMF Staff Note to G-20 } \\
\text { 2. Fifth Progress Report on the Implementation of the G-20 Data Gaps } \\
\text { Initiative } \\
\text { 3. IMF Note on Growth-Friendly Fiscal Policy } \\
\text { 4. IMF Note on Budget Institutions in G20 Countries } \\
\text { 5. IMF Note on Quantifying the Impact of G-20 Members' Growth } \\
\text { Strategies } \\
\text { 6. Advancing the Work on Foreign Currency Exposures } \\
\text { 7. G20 Macroeconomic Reform Priorities Report (IMF, OECD, World Bank) } \\
\text { 8. Quantifying the Impact of G-20 Members' Growth Strategies (OECD, IMF) }\end{array}$ \\
\hline
\end{tabular}




\begin{tabular}{|c|c|c|}
\hline Summit & $\begin{array}{l}\text { Organization and number of } \\
\text { reports submitted }\end{array}$ & Reports \\
\hline & Financial Stability Board $-8^{25}$ & $\begin{array}{l}\text { 1. Overview of Progress in the Implementation of the G20 } \\
\text { Recommendations for Strengthening Financial Stability } \\
\text { 2. Update on Financial Regulatory Factors Affecting the Supply of Long- } \\
\text { Term Investment Finance } \\
\text { 3. Overview of Progress in the Implementation of the G20 } \\
\text { Recommendations for Strengthening Financial Stability } \\
\text { 4. Transforming Shadow Banking into Resilient Market-based Financing. } \\
\text { An Overview of Progress and a Roadmap for } 2015 \\
\text { 5. Structural Banking Reforms: Cross-border Consistencies and Global } \\
\text { Financial Stability Implications } \\
\text { 6. Report to the G20 on Progress in Reform of Resolution Regimes and } \\
\text { Resolution Planning for G-SIFIs } \\
\text { 7. Progress Report on Transforming Shadow Banking into Resilient } \\
\text { Market-Based Financing } \\
\text { 8. Report to the G20 Brisbane Summit on the FSB's review of the } \\
\text { structure of its representation }\end{array}$ \\
\hline & World Bank - 10 & $\begin{array}{l}\text { 1. Recent Developments in Local Currency Bond Markets } \\
\text { 2. Overcoming Constraints to the Financing of Infrastructure. Success } \\
\text { stories and lessons learned: Country, sector and project examples of } \\
\text { overcoming constraints to the financing of infrastructure } \\
\text { 3. Overcoming Constraints to the Financing of Infrastructure. Sovereign } \\
\text { wealth funds and long-term development finance: risks and opportunities } \\
\text { 4. Practical solutions and models for addressing obstacles to institutional } \\
\text { investment in infrastructure in Developing Countries } \\
\text { 5. Optimizing World Bank Group Resources and Supporting } \\
\text { Infrastructure Financing } \\
\text { 6. A Multipronged Integrated Approach to the Development of Securities } \\
\text { Markets: the Deep Dive } \\
\text { 7. Transitional policies to assist the poor while phasing out inefficient } \\
\text { fossil fuel subsidies that encourage wasteful consumption } \\
\text { 8. Growth Strategies: G20 Emerging Market Economies } \\
\text { 9. Global Infrastructure Facility: Update for G20 Leaders } \\
\text { 10. Information Update on MDB Exposure Exchange Arrangements }\end{array}$ \\
\hline & $\begin{array}{l}\text { Organization for Economic } \\
\text { Cooperation and Development } \\
(\text { OECD })^{26}-13\end{array}$ & $\begin{array}{l}\text { 1. OECD Secretary-General's Report to G20 Leaders on Tax Matters } \\
\text { 2. Going for Growth 2014 } \\
\text { 3. Global Value Chains: Challenges, Opportunities and Implications for } \\
\text { Policy (OECD, WTO, World Bank) } \\
\text { 4. G20/OECD Report on Effective Approaches to Support Implementation } \\
\text { of the G20/OECD High-Level Principles on Long-Term Investment } \\
\text { Financing by Institutional Investors } \\
\text { 5. Pooling of Institutional Investors Capital - Selected case studies in } \\
\text { unlisted equity infrastructure } \\
\text { 6. How can competition contribute to the G20 commitment to raise } \\
\text { GDP by at least } 2 \% \text { ? } \\
\text { 7. Private financing and government support to promote long-term } \\
\text { investments in infrastructure } \\
\text { 8. OECD/INFE Progress Report on Financial Education } \\
\text { 9. Effective Approaches to Support the Implementation of the remaining } \\
\text { G20/OECD High-Level Principles of Financial Consumer Protection } \\
\text { 10. Promoting better labour market outcomes for youth (OECD, ILO) } \\
\text { 11. Preventing Unemployment and Underemployment From Becoming } \\
\text { Structural } \\
\text { 12. Effective Local Strategies to Boost Quality Job Creation, } \\
\text { Employment, and Participation } \\
\text { 13. OECD Report to G20 Development Working Group on the Impact } \\
\text { of Base Erosion and Profit Shifting in Low Income Countries }\end{array}$ \\
\hline & $\begin{array}{l}\text { International Labour } \\
\text { Organization (ILO) - } 3\end{array}$ & $\begin{array}{l}\text { 1. G20 labour markets: outlook, key challenges and policy responses } \\
\text { (ILO, OECD, World Bank) } \\
\text { 2. G20: Creating Safe and Healthy Workplaces for All } \\
\text { 3. Informality and the quality of employment in G } 20 \text { countries }\end{array}$ \\
\hline
\end{tabular}




\begin{tabular}{|c|c|c|}
\hline Summit & $\begin{array}{l}\text { Organization and number of } \\
\text { reports submitted }\end{array}$ & Reports \\
\hline & $\begin{array}{l}\text { World Trade Organization } \\
\text { (WTO) }-1\end{array}$ & 1. WTO Report on G-20 Trade Measures \\
\hline & $\begin{array}{l}\text { United Nations Conference } \\
\text { on Trade and Development } \\
\text { (UNCTAD) }-1\end{array}$ & 1. OECD/UNCTAD Report on G-20 Investment Measures \\
\hline & $\begin{array}{l}\text { Bank for International } \\
\text { Settlements (BIS) }-1\end{array}$ & $\begin{array}{l}\text { 1. BIS, FSB and IMF letter on progress regarding data gaps on foreign } \\
\text { currency exposures: Submissions by the BIS/FSB on risks from corporate } \\
\text { balance sheets and by the staff of the IMF }\end{array}$ \\
\hline & $\begin{array}{l}\text { International Organization } \\
\text { of Securities Commissions } \\
(\text { IOSCO })-3\end{array}$ & $\begin{array}{l}\text { 1. Review of the Implementation of IOSCO's Principles for Financial } \\
\text { Benchmarks by Administrators of Euribor, Libor and Tibor } \\
\text { 2. IOSCO Report on the Implementation of the Principles for Oil Price } \\
\text { Reporting Agencies } \\
\text { 3. IOSCO Final Report: Update to Survey on the Principles for the } \\
\text { Regulation and Supervision of Commodity Derivatives Markets }\end{array}$ \\
\hline & $\begin{array}{l}\text { Global Partnership for } \\
\text { Financial Inclusion (GPFI) } \\
-0\end{array}$ & No \\
\hline & $\begin{array}{l}\text { Basel Committee on Banking } \\
\text { Supervision }-1\end{array}$ & $\begin{array}{l}\text { 1. Implementation of Basel standards A report to } \mathbf{G} 20 \text { Leaders on } \\
\text { implementation of the Basel III regulatory reforms }\end{array}$ \\
\hline & $\begin{array}{l}\text { Financial Action Task Force } \\
\text { (FATF) }-1\end{array}$ & 1. Financial Action Task Force Progress Report to the G20 \\
\hline & $\begin{array}{l}\text { Food and Agriculture } \\
\text { Organization of the United } \\
\text { Nations }(\text { FAO })-1\end{array}$ & $\begin{array}{l}\text { 1. OPPORTUNITIES FOR ECONOMIC GROWTH AND } \\
\text { JOB CREATION IN RELATION TO FOOD SECURITY AND } \\
\text { NUTRITION (OECD, FAO) }\end{array}$ \\
\hline & In total: $\mathbf{5 1}$ & \\
\hline \multirow[t]{2}{*}{$\begin{array}{l}2015 \\
\text { Antalya, } \\
\text { Turkey }\end{array}$} & $\begin{array}{l}\text { International Monetary Fund } \\
\text { (IMF) }-9\end{array}$ & $\begin{array}{l}\text { 1. IMF Staff Note to G-20 } \\
\text { 2. Sixth Progress Report on the Implementation of the G-20 Data Gaps } \\
\text { Initiative } \\
\text { 3. IMF Sustainability Updates, October } 2015 \\
\text { 4. IMF Report on Measures Which are Both Macroprudential and } \\
\text { Capital Flow Management Measures-IMF Approach } \\
\text { 5. Work on Foreign Currency Exposures Report to G-20 Economies } \\
\text { 6. Options for Low Income Countries' Effective and Efficient Use of Tax } \\
\text { Incentives for Investment. A Report to the G20 Development Working } \\
\text { Group by the IMF, OECD, UN and World Bank } \\
\text { 7. Staff Background Paper for G20 Surveillance Note-International } \\
\text { Migration: Recent Trends, Economic Impacts, and Policy Implications } \\
\text { 8. Islamic Finance: Opportunities, Challenges, and Policy Options } \\
\text { 9. Update by the IMF and the OECD on Cooperation on Macro- } \\
\text { prudential and Capital Flow Management Measures }\end{array}$ \\
\hline & $\begin{array}{l}\text { Financial Stability Board }{ }^{27} \\
-10\end{array}$ & $\begin{array}{l}\text { 1. The Financial Crisis and Information Gaps } \\
\text { 2. Implementation and effects of the G20 financial regulatory reforms } \\
\text { 3. Implementation of the G20 financial regulatory reforms - Dashboard } \\
\text { 4. Transforming Shadow Banking into Resilient Market-based Finance: An } \\
\text { Overview of Progress } \\
\text { 5. Work on Foreign Currency Exposures } \\
\text { 6. Corporate Funding Structures and Incentives } \\
\text { 7. Report to the G20 on actions taken to assess and address the decline in } \\
\text { correspondent banking } \\
\text { 8. Disclosure task force on climate-related risks } \\
\text { 9. Removing Remaining Obstacles to Resolvability } \\
\text { 10. Total Loss-Absorbing Capacity (TLAC) Principles and Term Sheet }\end{array}$ \\
\hline
\end{tabular}




\begin{tabular}{|c|c|c|}
\hline Summit & $\begin{array}{l}\text { Organization and number of } \\
\text { reports submitted }\end{array}$ & Reports \\
\hline & World Bank - 5 & $\begin{array}{l}\text { 1. Note on G20 - WBG Singapore Workshop on Project Prioritization } \\
\text { and Preparation } \\
\text { 2. Capital Market Instruments to Mobilize Institutional Investors to } \\
\text { Infrastructure and SME Financing in Emerging Market Economies, } \\
\text { WBG/IMF/OECD Report to G20 Finance Ministers and Central Bank } \\
\text { Governors } \\
\text { 3. Leveraging Islamic Finance for SMEs. Joint WB-IsDB G20 Islamic } \\
\text { Finance Policy Paper } \\
\text { 4. PPP Guidelines: World Bank Group Infrastructure Deliverables. WBG } \\
\text { Reports to G20 Finance Ministers and Central Bank Governors } \\
\text { 5. WBG/OECD Project Checklist for PPPs }\end{array}$ \\
\hline & $\begin{array}{l}\text { Organization for Economic } \\
\text { Cooperation and Development } \\
(\text { OECD })^{28}-27\end{array}$ & 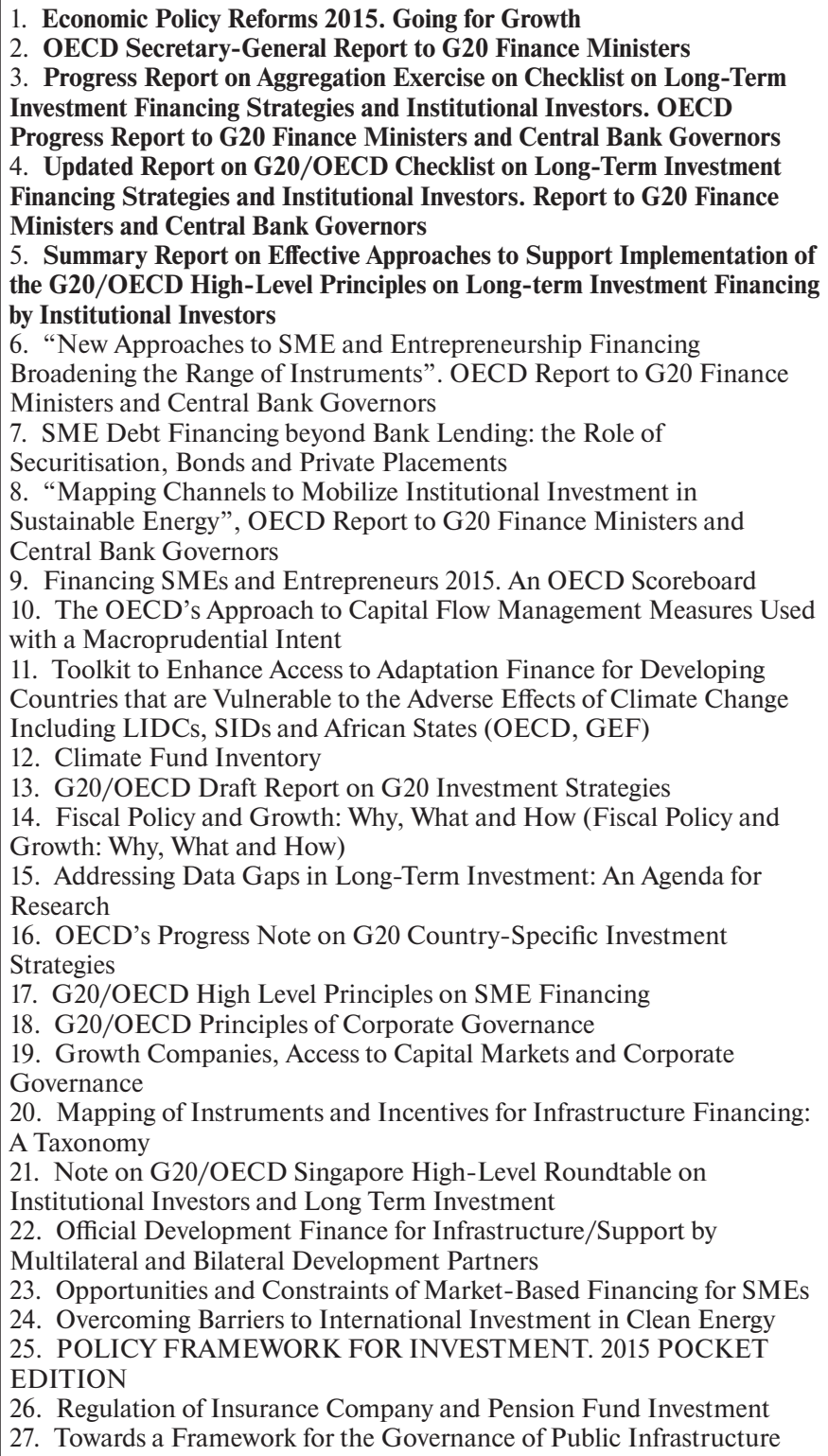 \\
\hline
\end{tabular}




\begin{tabular}{|c|c|c|}
\hline \multirow[t]{2}{*}{ Summit } & $\begin{array}{l}\text { Organization and number of } \\
\text { reports submitted }\end{array}$ & Reports \\
\hline & $\begin{array}{l}\text { International Labour } \\
\text { Organization (ILO) }-3\end{array}$ & $\begin{array}{l}\text { 1. The Contribution of Labour Mobility to Economic Growth } \\
\text { 2. Income inequality and labour income share in G20 countries: Trends, } \\
\text { Impacts and Causes } \\
\text { 3. G20 Labour Markets in 2015: Strengthening the Link between Growth } \\
\text { and Employment }\end{array}$ \\
\hline & $\begin{array}{l}\text { World Trade Organization } \\
\text { (WTO) }-1\end{array}$ & $\begin{array}{l}\text { 1. WTO Report on G-20 Trade Measures (mid-October } 2014 \text { to mid- } \\
\text { May 2015) }\end{array}$ \\
\hline & $\begin{array}{l}\text { United Nations Conference } \\
\text { on Trade and Development } \\
\text { (UNCTAD) }-1\end{array}$ & 1. OECD/UNCTAD Report on G-20 Investment Measures \\
\hline & $\begin{array}{l}\text { Bank for International } \\
\text { Settlements (BIS) }-1-\end{array}$ & 1. Work on Foreign Currency Exposures (IMF, BIS, FSB) \\
\hline & $\begin{array}{l}\text { Global Partnership for } \\
\text { Financial Inclusion (GPFI) } \\
-2\end{array}$ & $\begin{array}{l}\text { 1. GPFI Report to the G20 Leaders } \\
\text { 2. G20 Financial Inclusion Action Plan (FIAP) Progress Report 2010- } \\
\text { 2014 }\end{array}$ \\
\hline & $\begin{array}{l}\text { Basel Committee on Banking } \\
\text { Supervision }-1\end{array}$ & $\begin{array}{l}\text { 1. Implementation of Basel standards. A report to G20 Leaders on } \\
\text { implementation of the Basel III regulatory reforms }\end{array}$ \\
\hline & FATF -1 & 1. Report on the Terrorist Financing, FATF's Report to the G20 Leaders \\
\hline & In total: 61 & \\
\hline \multirow[t]{8}{*}{$\begin{array}{l}2016 \\
\text { Hangzhou, } \\
\text { China }\end{array}$} & $\begin{array}{l}\text { International Monetary Fund } \\
\text { (IMF) }-7\end{array}$ & $\begin{array}{l}\text { 1. IMF Staff Note to G-20 } \\
\text { 2. Reinvigorating Trade to Support Growth: A path Forward } \\
\text { 3. Staff Note for the G20-The Role of the SDR-Initial Considerations } \\
\text { 4. Staff Background Paper for G-20 Surveillance Note: Priorities for } \\
\text { Structural Reforms in G-20 Countries } \\
\text { 5. Enhancing the Effectiveness of External Support in Building Tax } \\
\text { Capacity in Developing Countries } \\
\text { 6. International Organizations Take Major Step to Boost Global } \\
\text { Cooperation in Tax Matters; April 19, } 2016 \\
\text { 7. The Platform for Collaboration on Tax; Concept Note; April 19, } 2016\end{array}$ \\
\hline & Financial Stability Board -0 & To be submitted \\
\hline & World Bank -0 & To be submitted \\
\hline & $\begin{array}{l}\text { Organization for Economic } \\
\text { Cooperation and Development } \\
(\text { OECD })-2\end{array}$ & $\begin{array}{l}\text { 1. OECD Secretary-General Report to G20 Finance Ministers } \\
\text { 2. Economic Policy Reforms: Going for Growth } 2016\end{array}$ \\
\hline & $\begin{array}{l}\text { International Labour } \\
\text { Organization (ILO) }-0\end{array}$ & To be submitted \\
\hline & $\begin{array}{l}\text { World Trade Organization } \\
\text { (WTO) }-1\end{array}$ & 1. WTO Report on G-20 Trade Measures \\
\hline & $\begin{array}{l}\text { United Nations Conference } \\
\text { on Trade and Development } \\
\text { (UNCTAD) }-1\end{array}$ & $\begin{array}{l}\text { 1. OECD/UNCTAD Report on G-20 Investment Measures - World } \\
\text { Trade Organization }\end{array}$ \\
\hline & In total: 11 & \\
\hline
\end{tabular}

${ }^{16}$ IMF and the Group of Twenty. Available at: http://www.imf.org/external/np/g20/ (accessed: 29 August 2016) (used for all summits).

${ }_{17}$ Reports to the G20. Available at: http://www.fsb.org/publications/g20-reports/ (accessed: 29 August 2016) (used for all summits).

${ }_{18}$ ILO reports for the G20. Available at: http://www.ilo.org/global/about-the-ilo/how-the-ilo-works/ multilateral-system/g20/reports/lang--en/index.htm (accessed: 29 August 2016) (used for all summits).

19 Pittsburgh, United States 2009. Available at: https://www.oecd.org/g20/summits/pittsburgh/ (accessed: 29 August 2016). 2016).

${ }^{20}$ Seoul, Korea 2010. Available at: https://www.oecd.org/g20/summits/seoul/ (accessed: 29 August

${ }^{21}$ Cannes, France 2011. Available at: https://www.oecd.org/g20/summits/cannes/ (accessed: 29 August 2016). 

Group.

${ }^{22}$ The indicated documents are mainly contributions to the G20 Commodity Markets Sub Working

${ }^{23}$ Los Cabos, Mexico 2012. Available at: https://www.oecd.org/g20/summits/los-cabos/ (accessed: 29 August 2016).

${ }^{24}$ St. Petersburg, Russian Federation 2013. Available at: https://www.oecd.org/g20/summits/saintpetersburg/ (accessed: 29 August 2016).

$25+$ a number of consultative documents. Available at: http://www.fsb.org/2014/11/fsb-reports-to-g20brisbane-summit-on-progress-in-financial-regulatory-reforms/ (accessed: 29 August 2016).

${ }^{26}$ Brisbane, Australia 2014. Available at: https://www.oecd.org/g20/summits/brisbane/ (accessed: 29 August 2016).

${ }_{27}$ Monitoring Reports - November 2015. Available at: http://www.fsb.org/what-we-do/implementation-monitoring/progress-reports-to-the-g20/duplicate-monitoring-reports-november-2015/ (accessed: 29 August 2016).

${ }^{28}$ Antalya, Turkey, 15-16 November 2015. Available at: https://www.oecd.org/g20/summits/antalya/ (accessed: 29 August 2016).

Total number of materials per each organization since G20 Washington summit

\begin{tabular}{|l|c|}
\hline \multicolumn{1}{|c|}{ Organization } & Total number of materials \\
\hline International Monetary Fund (IMF) & 46 \\
\hline Financial Stability Board (FSB) & 46 \\
\hline World Bank & 32 \\
\hline $\begin{array}{l}\text { Organization for Economic Cooperation and } \\
\text { Development (OECD) }\end{array}$ & 17 \\
\hline International Labour Organization (ILO) & 9 \\
\hline World Trade Organization (WTO) & 10 \\
\hline $\begin{array}{l}\text { United Nations Conference on Trade and } \\
\text { Development (UNCTAD) }\end{array}$ & 3 \\
\hline International Energy Agency (IEA) & 4 \\
\hline Financial Action Task Force (FATF) & 6 \\
\hline Bank for International Settlements (BIS) & 5 \\
\hline Basel Committee on Banking Supervision & 9 \\
\hline $\begin{array}{l}\text { International Organization of Securities } \\
\text { Commissions (IOSCO) }\end{array}$ & 5 \\
\hline Global Partnership for Financial Inclusion (GPFI) & 3 \\
\hline $\begin{array}{l}\text { Food and Agriculture Organization of the United } \\
\text { Nations (FAO) }\end{array}$ & 2 \\
\hline African Development Bank & \\
\hline
\end{tabular}

